\title{
1 Crustal structure of the Mid Black Sea High from wide-angle seismic
}

2 data

3 D. J. Shillington ${ }^{1}$, T. A. Minshull ${ }^{2}$, R. A. Edwards ${ }^{3}$ and N. White ${ }^{4}$

4

$5 \quad{ }^{1}$ Lamont-Doherty Earth Observatory, 61 Route 9W, Palisades, NY10964, USA;

6 djs@1deo.columbia.edu

$7 \quad{ }^{2}$ Ocean and Earth Science, National Oceanography Centre Southampton, University of Southampton,

8 European Way, Southampton SO14 3ZH, UK; tmin@noc.soton.ac.uk

$9 \quad{ }^{3}$ National Oceanography Centre, European Way, Southampton SO14 3ZH, UK;

10 r.edwards@edwardsgeo.co.uk

$11{ }^{4}$ Bullard Laboratories, University of Cambridge, Madingley Road, Cambridge CB3 0EZ;

12 nwhite@esc.cam.ac.uk

\section{Abstract}

The Mid Black Sea High comprises two en-echelon basement ridges, the Archangelsky and Andrusov Ridges that separate the western and eastern Black Sea basins. The sediment coverage above these ridges has extensive seismic reflection coverage, but the crustal structure beneath is poorly known. We present results from a densely sampled wide-angle seismic profile, coincident with a pre-existing seismic reflection profile, which elucidates the crustal structure. We show that the basement ridges are covered by c. 1-2 km of pre-rift sedimentary rocks. The Archangelsky

22 Ridge has higher pre-rift sedimentary velocities and higher velocities at the top of basement $(\sim 6 \mathrm{~km} / \mathrm{s})$. The Andrusov Ridge has lower pre-rift sedimentary velocities

24 and velocities less than $5 \mathrm{~km} / \mathrm{s}$ at the top of the basement. Both ridges are underlain 25 by c. $20-\mathrm{km}$ thick crust with velocities reaching c. $7.2 \mathrm{~km} / \mathrm{s}$ at their base, interpreted 26 as thinned continental crust. These high velocities are consistent with the geology of 
the Pontides, which is formed of accreted island arcs, oceanic plateaux and accretionary complexes. The crustal thickness implies crustal thinning factors of $\sim 1.5$ 2. The differences between the ridges reflect different sedimentary and tectonic histories.

\section{Introduction}

Several episodes of extension and shortening have shaped the Black Sea region since Permian times [e.g., Nikishin et al., 2003; Robertson et al., 2004; Yilmaz et al., 1997], which led to the addition of a series of volcanic arcs, oceanic plateaux and accretionary complexes to the Eurasian margin [e.g., Okay et al., 2013]. The basin is thought to have formed in a back-arc extensional environment because of its close spatial association with the subduction of both the Paleo- and Neo-Tethys Oceans [e.g., Letouzey et al., 1977], but the timing and style of this opening history remain controversial, partly because the thick sediment coverage means that the oldest sedimentary fill has not been drilled [Banks et al., 1997; Nikishin et al., 2015a; Okay et al., 1994; Zonenshain and Le Pichon, 1986; Okay et al., this volume]. The Black Sea is commonly subdivided into eastern and western basins; these sub-basins are separated by the Mid Black Sea High (MBSH), a system of buried basement ridges that runs SW-NE [Fig. 1; e.g., Nikishin et al., 2015b; Okay et al., 1994].

The opening of the western basin may be estimated from the ages of arc volcanic rocks in the western Pontides and from associated plate reconstructions; this evidence suggests a Middle to Upper Cretaceous age [Görür, 1988; Okay et al., 1994; Okay et al., this volume]. Based on seismic refraction and gravity data, the crust in the centre of the basin is $7-8 \mathrm{~km}$ thick and has velocities consistent with the presence of oceanic 
crust, suggesting that rifting culminated in seafloor spreading [Belousov et al., 1988;

Letouzey et al., 1977; Starostenko et al., 2004].

The age and nature of the eastern basin are more controversial. The basin is thought to have formed by rotation of the Shatsky Ridge relative to the Mid Black Sea High [Figs. 1 and 2; Nikishin et al., 2003; Okay et al., 1994]. The main phase of opening has been interpreted as Jurassic, Cretaceous [Nikishin et al., 2003; Nikishin et al., 2015a; Okay et al., 1994; Zonenshain and Le Pichon, 1986], Early Eocene/Paleocene [Banks et al., 1997; Robinson et al., 1995; Shillington et al., 2008], or Eocene [Kazmin et al., 2000; Vincent et al., 2005]. Based on gravity and early seismic data, the crust in the centre of this basin was inferred to have a thickness of $\sim 10-11 \mathrm{~km}$ and seismic velocities are lower than those of typical oceanic crust, suggesting the presence of thinned continental crust [Belousov et al., 1988; Starostenko et al., 2004]. However, results from a wide-angle seismic experiment in 2005 suggest that the crustal structure varies along the basin, with the western part floored by thinned continental crust (7-9 km thick), and thicker, higher velocity crust below the eastern part that is attributed to magmatically robust early seafloor spreading resulting in early oceanic crust that is thicker and has higher velocities than average oceanic crust [Shillington et al., 2009].

\section{The Mid Black Sea High itself is divided into the en-echelon Archangelsky and} Andrusov ridges, which have different sediment thicknesses and are inferred to have different structure and origin [Nikishin et al., 2015b; Robinson et al., 1996] (Fig. 1b). These ridges are poorly explored compared to the basins either side. The Andrusov 
76 Ridge is inferred to have formed during early opening of the eastern basin [Nikishin et 77 al., 2015a; Okay et al., 1994; Robinson et al., 1996]. This rifting event is inferred to 78 have been amagmatic in this part of the basin [Shillington et al., 2009]. Alternatively, 79 the Andrusov Ridge is interpreted as a marginal ridge associated with the opening of 80 the western basin along the West Crimean transform fault [Tari et al., 2015]. The 81 Archangelsky Ridge was formed by the opening of the Sinop Trough, which is linked 82 to the western basin and is interpreted to have opened in Cretaceous to Palaeocene 83 times [Espurt et al., 2014; Robinson et al., 1996], with ongoing extension into the 84 Miocene [Espurt et al., 2014; Rangin et al., 2002]. An Upper Cretaceous sedimentary 85 sequence and lower Cretaceous platform carbonate rocks have been dredged where 86 the pre-rift sequences outcrops on the flank of Archangelsky Ridge, providing an 87 upper limit on its age of formation [Rudat and Macgregor, 1993; Robinson et al. $881996]$. After their formation, both ridges have also experienced compressional deformation [Espurt et al., 2014; Rangin et al., 2002]. This region has likely experienced multiple episodes of compression, continuing to the present; apatite fission track data and paleostress measurements onshore show that inversion of rifting structure onshore occurred as early as $55 \mathrm{Ma}$ [Saintot \& Angelier, 2002; Espurt et al., 2014] following extension leading to opening of eastern Black Sea. Active compression continues around margins of easternmost Black Sea today based on seismicity and onshore geology, particularly in the Caucaus [Saintot \& Angelier, 2002; Gobarenko et al. 2016].

Published constraints on crustal structure beneath the ridges are sparse. Seismic refraction data acquired in the 1960s were recently re-analysed using more modern 
ray-tracing techniques [Yegorova and Gobarenko, 2010]. This analysis suggests a

102 crustal thickness of c. $20 \mathrm{~km}$ beneath both ridges and crustal velocities in the range

$1036.0-7.0 \mathrm{~km} / \mathrm{s}$, interpreted as representing thinned continental crust. A more modern

104 profile crossing the southern part of Archangelsky Ridge suggests that here, crustal

105 thickness reaches c. $25 \mathrm{~km}$ [Shillington et al., 2009]. In this paper we present results

106 from a modern, densely sampled wide-angle seismic profile that crosses the Andrusov

107 Ridge close to its southern tip and the Archangelsky Ridge at its northern tip (Fig. 1).

\section{Wide-Angle Seismic Data}

111 An onshore-offshore wide-angle seismic dataset was collected in 2005 using the R/V

112 Iskatel to determine the deep structure of the eastern basin and Mid Black Sea High.

113 Seventeen four-component short-period ocean-bottom seismometers (OBSs) from

114 GeoPro were deployed on Profile 4 across the Andrusov Ridge (Fig. 1; Table 1), and

115 they recorded seismic shots generated from an airgun array with a total volume of

$1163140 \mathrm{in}^{3}$ that was triggered every $90 \mathrm{~s}$ (shot spacing c. $150 \mathrm{~m}$ ). Profile 4 was co-

117 located with existing industry seismic reflection data, 91-106 (Figs. 1 and 2).

\section{Data Analysis}

\section{Data processing}

122 Water-wave arrivals were used to relocate OBS positions on the seafloor, using a

123 seafloor depth determined by echosounder at the position of each deployment and a

124 water velocity of $1.47 \mathrm{~km} / \mathrm{s}$. Relocated positions were typically less than $75 \mathrm{~m}$ from

125 deployment positions, but three OBS have relocated positions that differ by 200-300 
$\mathrm{m}$ from deployment positions. We applied a minimum phase band-phase filter with

127 corners at $3,5,15,20 \mathrm{~Hz}$ to suppress noise, and applied offset dependent gains and a 128 reduction velocity of $8 \mathrm{~km} / \mathrm{s}$.

\section{Phase identification}

131 We identified refractions and wide-angle reflections from the pre-rift sedimentary

132 section, the crust and the upper mantle that could be consistently identified on a

133 majority of the receiver gathers. Phase interpretations and velocity models of the

134 overlying syn- and post-rift sedimentary section have been presented elsewhere [Scott

135 et al., 2009]. Travel-time picks were made manually of the following phases:

136 reflections off the base of an interpreted pre-rift sedimentary layer (PprP), crustal

137 refractions $(\mathrm{Pg})$, reflections from the base of the crust $(\mathrm{PmP})$, and upper mantle

138 refractions (Pn) (Fig. 3; Table 2). Reflections from the base of the interpreted pre-rift

139 sedimentary section are observed from near-vertical incidence to offsets up to $\sim 30 \mathrm{~km}$

140 and have picking uncertainties of $30-50 \mathrm{~ms}$. Crustal refractions are observed as first

141 arrivals at offsets from $\sim 12-100 \mathrm{~km}$ and have picking uncertainties of 30 to $75 \mathrm{~ms}$.

142 Reflections from the base of the crust are observed at offsets between $\sim 35-100 \mathrm{~km}$;

143 the offsets where PmP reflections are observed vary significantly over the line,

144 indicating variations in crustal thickness. Likewise, the amplitude and character of

145 PmP reflections is also highly variable and thus picks of this phase have relatively

146 high uncertainties of $125 \mathrm{~ms}$. We observed limited and relatively low amplitude

147 refractions interpreted to arise from the upper mantle in some receiver gathers; these

148 refractions are weak and variable, and have a picking uncertainty of $125 \mathrm{~ms}$. Figure 3

149 shows examples of OBS data, phase identifications, and associated ray paths. 
151 Wide-angle reflections interpreted to originate from the base of the interpreted pre-rift

152 sedimentary layer can be linked to a coincident industry seismic reflection profile

153 (BP91-106, Fig. 2). Picks of this interface were thus also made on the reflection

154 profile (Fig. 2, red dotted line) and included in the inversion. We assigned an

155 uncertainty of $100 \mathrm{~ms}$ to these picks to account for uncertainties in associating MCS

156 and wide-angle reflections and for small-scale variations in interface geometry that

157 cannot be recovered by inversion.

158

159 Velocity modelling

160 The travel-time picks described above were used to invert for velocities of the pre-rift

161 sedimentary section, crust and upper mantle. We used JIVE3D, a regularized

162 tomographic inversion code [Hobro et al., 2003], which solves for a minimum

163 structure layer-interface model that fits the data within its uncertainties. Velocities

164 within each layer and interface depths are defined by splines and vary smoothly;

165 interfaces represent velocity discontinuities. The forward problem involves tracing a

166 fan of rays from each OBS position through specified layers in the model to generate

167 predicted travel times (i.e., ray shooting); the ray that arrives within a distance

168 tolerance of the target with the minimum travel time is used. Inversion involves a

169 sequence of linear steps to reduce the difference between observed and predicted

170 travel times (e.g., Figs. 4d and 5d) and satisfy other smoothing criteria. In each step,

171 smoothing is reduced and structure is allowed to develop to improve data fit.

172 Smoothing is implemented during inversion by minimizing a function of data misfit

173 and model roughness.

174 
175 We employed a layer stripping approach for this line. The previously determined

176 velocity structure of the post- and syn-rift sediment from Scott et al. [2009] was held

177 fixed. We first inverted for the interpreted pre-rift sediment layer using picks of wide-

178 angle reflections from OBS data and vertically-incident reflections from the

179 coincident seismic reflection profile (Fig. 2). This layer was then held fixed during

180 the inversion for crustal and upper mantle structure. The inversion converged more

181 quickly and stably for both the pre-rift sedimentary section and for the crustal/mantle

182 sections when we inverted for them separately. However, inverting for all layers

183 simultaneously yielded the same overall velocity structure. We also performed two

184 different inversions for crust/mantle structure. The first inversion used only first

185 arriving refractions from the crust and mantle. The second inversion included

186 interpreted wide-angle reflections from the base of the crust $(\mathrm{PmP})$ in addition to the

187 first arrivals. The purpose of performing two inversions for the crust and upper

188 mantle structure was to assess which features in the model arise from the inclusion of

189 wide-angle reflections from the base of the crust; identifying PmP is associated with

190 more uncertainty and subjectivity than first arrivals. We are most confident of

191 features that are present in both the first-arrival and reflection/refraction tomographic

192 inversions, and more cautious of features that are primarily constrained by the PmP

193 reflections.

194

195 We used a grid spacing of $1 \mathrm{~km} \times 0.5 \mathrm{~km}$ in the pre-rift interval, and $1 \times 1 \mathrm{~km}$ in the

196 crust and upper mantle. For both inversions, we applied twice as much horizontal

197 smoothing than vertical smoothing and allowed more interface roughness than

198 velocity roughness. A simple 1D velocity model and constant interfaces were used

199 for the starting models in both inversions. 
201 The inversion for the pre-rift layer used 825 picks from the OBS data and 129 picks

202 from the MCS data. The final model has a chi-squared misfit of 1.29 and RMS

203 residual of $72 \mathrm{~ms}$ if only the OBS picks are included. Larger misfits are associated

204 with the MCS picks since they include smaller scale variations in interface geometry

205 than can be recovered by the inversion. If these are included, the overall chi-squared

206 misfit is 1.65 , and the RMS residual is $90 \mathrm{~ms}$.

208 The first-arrival inversion for the crust and upper mantle structure used 5732 picks.

209 The final model has a chi-squared value of 0.96 and an RMS residual of $76 \mathrm{~ms}$. The

210 reflection/refraction inversion used 7085 picks. The final model has a chi-squared

211 value of 2.23 and an RMS residual of $127 \mathrm{~ms}$.

213 Based on ray coverage, data fit and testing of different inversion parameterizations,

214 we discuss the confidence that should be placed in different features of our final

215 models. The upper crustal structure is very well sampled by ray coverage associated

216 with our travel-time picks, and refractions from this part of the model have relatively

217 low misfits (Figs. 3-5). Similar features are apparent in both the reflection/refraction

218 tomography and the first-arrival tomography. Thus, we consider the variations in

219 upper crustal velocity structure between the Andrusov and Archangelsky Ridge to be

220 a robust result (Figs. $4 \mathrm{~b}$ and 5b). The lowermost crustal sections beneath the

221 Andrusov and Archangelsky ridges are only constrained by sparse turning wave

222 coverage and relatively sparse reflections from the base of the crust (Figs. 3 and 5).

223 Because the uppermost part of the lower crust is sampled by reversed refracted

224 arrivals, we are confident that high velocities are required. However, we cannot 
constrain the velocity gradient of the lowermost crust or absolute velocity at the very

226 base of the lower crust, and there are thus tradeoffs between velocities in the

227 lowermost crust and depth to the base of the crust. Both wide-angle reflections and

228 vertically incident reflections constrain the interpreted pre-rift sedimentary layer on

229 top of the MBSH. We find relatively high data misfits for phases defining this layer

230 (Table 2), which we attribute to substantial lateral variability that cannot be accounted

231 for in the analysis of OBS spaced at $\sim 15 \mathrm{~km}$. However, we think that the large-scale

232 patterns of thickness and velocity are well constrained.

234 Although we obtained an excellent misfit for the first-arrival tomography model (chi235 squared value of 0.96 ), our favored model from reflection/refraction tomography has 236 a higher chi-squared value of 2.23. We relaxed the data misfit criteria to obtain a 237 relatively smooth model; models with better data fit were substantially rougher. We

238 feel this choice is justified by the likely three-dimensionality of velocity structure

239 beneath these complex ridges and the complexity of sedimentary, crustal and upper 240 mantle phases observed on OBS.

\section{Results and Discussion}

244 The final velocity models across the Mid-Black Sea High provide constraints on the 245 deep sedimentary and crustal structure of this composite ridge.

\section{Sedimentary rocks overlying the Mid Black Sea High}

248 The flat-lying post-rift sedimentary rocks exhibit a low-velocity zone in the Miocene

249 Maikop formation (Figs. 5 and 6) that extends across the eastern basin and also 
appears to be present above parts of the MBSH and in the Sinop Trough [Fig. 6; Scott

251 et al., 2009]. The low-velocity zone is attributed to fluid overpressure, and fluid

252 pressures close to lithostatic have been inferred [Scott et al., 2009], though application

253 of a more sophisticated approach in the eastern basin [Marin-Moreno et al., 2013a; b]

254 suggests that fluid pressures are lower than those derived from the empirical

255 approaches of Scott et al. [2009].

257 Wide-angle reflections in the OBS data (Fig. 3) and reflections in the reflection

258 profile (Fig. 6) define a distinct layer with a thickness of 1-2 km and velocities of 3.0-

$2594.75 \mathrm{~km} / \mathrm{s}$ on top of the Andrusov and Archangelsky Ridges (Fig. 5). Based on the

260 character of this layer in the reflection profile, dredging on the Archangelsky Ridge

261 and drilling of the Andrusov Ridge, we interpret this layer to represent a sequence of

262 prerift Upper Cretaceous sedimentary rocks [Rudat \& McGregor, 1993; Aydemir \&

263 Demirer, 2013]. This layer is characterized by brightly reflective layering in the

264 reflection profile, which is consistent with a sedimentary origin (Figs. 2, 6). Drilling

265 on Andrusov Ridge at Sinop-1 recovered a relatively thin layer of Upper Cretaceous

266 carbonate rocks [Aydemir \& Demirer, 2013]. Aydemir \& Demirer [2013] suggest that

267 the thickness of this interval would be strongly controlled by basement topography at

268 the time of deposition and thus be highly variable, which may explain why we appear

269 to observe a thicker Upper Cretaceous layer on Profile 4. A similar sequence overlies

270 the Shatsky Ridge to the north [Fig. 1; Nikishin et al., 2015b; Robinson et al., 1996].

272 The base of this layer is marked by a bright, continuous reflection in the reflection

273 profile (Fig. 6), which has been interpreted to mark the top of Lower Cretaceous

274 platform carbonate rocks [Rudat \& McGregor, 1993; Robinson et al., 1996]. Based on 
dredging results on the shallow part of the Archangelsky ridge, we interpret the uppermost basement beneath this reflection as being composed of Lower Cretaceous platform carbonate rocks and other older prerift sedimentary rocks. Platform

278 carbonate rocks are expected to have similar P-wave velocities to upper crystalline 279 crust [Christensen \& Mooney, 1995], so it is not possible for us to definitely identify 280 carbonate rocks or quantify their thickness, but the nearby dredging results suggest 281 prerift sedimentary rocks are likely present in the uppermost basement here. The 282 uppermost basement beneath the prominent reflection described above reaches 6-6.25 $283 \mathrm{~km} / \mathrm{s}$ beneath the top of the Archangelsky Ridge, and drops to c. $4.5 \mathrm{~km} / \mathrm{s}$ beneath the 284 Andrusov Ridge. The overlying layer interpreted to represent Upper Cretaceous 285 prerift sedimentary rocks also has significantly higher velocities beneath 286 Archangelsky Ridge than beneath Andrusov Ridge. These differences may be 287 attributed to several factors. First, although Archangelsky Ridge is generally a 288 shallower feature (Fig. 1), at the location of Profile 4 it is more deeply buried, so the 289 pre-rift sedimentary rocks may have undergone greater compaction and diagenesis.

290 Secondly, seismic reflection data suggest that the Andrusov Ridge is disrupted by 291 more faults than the Archangelsky Ridge [Robinson et al., 1996], and fracturing 292 associated with these faults may reduce the velocity by creating zones of higher 293 porosity and/or causing an elongation of pores, which have a bigger impact on elastic 294 properties [Töksöz et al., 1976]. Thirdly, other differences in lithology may 295 contribute to observed variations in velocity. Finally, the low-velocity layer in the 296 post-rift directly abuts the Andrusov Ridge, but is separated from Archangelsky Ridge 297 by a layer of higher-velocity material. Therefore it is possible that fluid overpressure 298 is transmitted into pre-rift sedimentary rocks on the Andrusov Ridge but not on the 299 Archangelsky Ridge. 


\section{Crustal structure and Implications for Tectonic Evolution}

302 The Andrusov and Archangelsky Ridges exhibit distinctly different crustal velocity 303 structures. As described in the previous section, the Archangelsky Ridge has higher 304 velocities in the uppermost basement $(6-6.25 \mathrm{~km} / \mathrm{s})$ and a relatively low velocity 305 gradient $(\sim 0.075 \mathrm{~km} / \mathrm{s} / \mathrm{km})$. In contrast, the Andrusov ridge has velocities in the 306 shallow basement as low as $4.5 \mathrm{~km} / \mathrm{s}$ and a high velocity gradient in the upper $10 \mathrm{~km}$ 307 of $0.25 \mathrm{~km} / \mathrm{s} / \mathrm{km}$. These differences might be associated with different degrees of 308 fracturing of platform carbonate rocks (see previous section) or of crystalline rocks, or 309 might arise because the prerift sedimentary sequence within the basement is thicker 310 beneath Andrusov Ridge, as perhaps suggested by seismic reflection data (Fig. 2).

312 Beneath both ridges, the velocity gradient is reduced in the lower crust, and velocities 313 reach a maximum of 7.2-7.3 km/s at the base of the crust (Fig. 5). These velocities 314 are somewhat higher than those observed beneath Archangelsky Ridge on Profile 3 $315(\sim 6.75-7 \mathrm{~km} / \mathrm{s})$ [Shillington et al., 2009] (Fig. 1), and may indicate the presence of a 316 more mafic pre-rift crust [e.g., Christensen and Mooney, 1995]. Rifting to form the 317 eastern Black Sea occurred in a series of terranes accreted to the Euroasian margin, 318 which include volcanic arcs and oceanic plateaux, both of which are typified by high319 velocity lower crust in modern analogues [Calvert, 2011; Kodaira et al., 2007;

320 Shillington et al., 2004].

322 These velocities are also only slightly lower than lower-crustal velocities observed in 323 crust within the centre of the eastern part of the Eastern Basin [Shillington et al., 324 2009], which were interpreted as evidence for new magmatic crust formed during 
magma rich rifting and early spreading. However, the relationship between lower crustal velocity and crustal thickness suggests that synrift magmatism is not responsible for the high lower crustal velocities beneath the MBSH. In the eastern part of the Eastern Basin [Shillington et al., 2009] and at other volcanic rifted margins worldwide [e.g., Holbrook and Kelemen, 1993; White et al., 2008], high-velocity lower crust $(\sim 7.4-7.5 \mathrm{~km} / \mathrm{s})$ interpreted to represent mafic synrift intrusions is most prominent in the area of crustal thinning. In contrast, the highest velocities observed beneath the MBSH occur in the thickest crust and do not increase towards the thinned margins of the ridge. Consequently, we propose that high lower crustal velocities beneath the MBSH represent high velocities associated with accreted volcanic arcs and oceanic plateaux in the pre-rift crust. Hence our observations from Profile 4 is consistent the view that extension in the western part of the eastern Black Sea Basin was largely amagmatic [Shillington et al., 2009].

The crustal layer, that may include platform carbonate rocks and possibly other prerift sedimentary rocks, thickens beneath both ridges to reach a maximum of $20-23 \mathrm{~km}$ (Fig. 5). Between the two ridges, it decreases to c. $16 \mathrm{~km}$, providing evidence that the modest increase in sediment thickness between the two ridges (Fig. 1) is associated with crustal-scale extension. Although the Archangelsky Ridge is deeply buried at the location of Profile 4 (Fig. 1), it clearly remains a major crustal feature at this location. Uppermost mantle velocities are a little below $8 \mathrm{~km} / \mathrm{s}$. Based on teleseismic receiver functions, gravity data and limited wide-angle seismic constraints, the crustal thickness onshore Turkey in the vicinity of Archangelsky Ridge is c. $35 \mathrm{~km}$ [Ozacar et al., 2010; Yegorova et al., 2013], with thicker crust farther east where it is affected more by compressional deformation. Therefore the crust along Profile 4 has been 
thinned by a factor of $1.5-2$. The degree of thinning is somewhat lower than inferred

351 by Shillington et al. [2008] based on the relationship between sediment thickness and 352 thinning factor on a well-constrained profile; this relationship gives a thinning factor 353 of 2-2.5 along most of Profile 4 (Fig. 7). One possible explanation for this difference 354 is that the "crust" of the Mid Black Sea High may include sections of pre-rift 355 sedimentary rocks that are not a part of the unthinned crustal section onshore [Okay et $356 a l$, this volume].

\section{Conclusions}

359 From our analysis of data from a wide-angle seismic profile across the Mid Black Sea 360 High, comprising the en echelon Archangelsky and Andrusov ridges, we conclude 361 that:

362 1. The basement highs are covered by at least $1-2 \mathrm{~km}$ layer of pre-rift 363 sedimentary rocks overlying a higher-velocity basement that may include pre364 rift sedimentary rocks, including platform carbonates that cannot be readily 365 distinguished from underlying crystalline crust.

2. The pre-rift sedimentary rocks and upper basement have higher velocities on the Archangelsky Ridge and lower velocities on the Andrusov Ridge. These differences could be explained by different amounts of faulting or changes in the abundance and/or composition of prerift sedimentary rocks.

3. The lower crust has a low velocity gradient and velocities exceed $7.0 \mathrm{~km} / \mathrm{s}$ at its base; the velocity structure is consistent with the presence of a mafic prerift crust with little magmatic addition during rifting. 
4. The crust is $20-23 \mathrm{~km}$ thick beneath the ridges and c. $16 \mathrm{~km}$ thick between them, representing thinning factors of 1.5-2.0 compared to adjacent crust in northeastern Turkey.

376

\section{Acknowledgments}

378 We thank T. Besevli, G. Coskun, A. Demirer, M. Erduran, S. Jones, R. O’Connor, B.

379 Peterson, A. Price, K. Raven, and M. Shaw-Champion and the officers, crew and 380 technical team aboard $R / V$ Iskatel for their support during the acquisition and analysis

381 of this dataset. This work was supported by the Natural Environment Research

382 Council (UK) (NER/T/S/2003/00114 and NER/T/S/2003/00885), BP and the Turkish

383 Petroleum Company (TPAO). BP and TPAO generously provided access to the

384 seismic reflection data. We also thank N. Hodgson and an anonymous reviewer for

385 constructive comments that greatly improved the manuscript. 
389 Figure 1. a. Elevation/bathymetry of Black Sea region from GEBCO showing the 390 location of 2005 onshore/offshore seismic refraction experiment. Shot lines are 391 indicated with white lines, OBS are shown with white circles and seismometers 392 deployed onshore shown with white triangles. OBS from Line 4, which are used in 393 this study, are indicated with solid circles. Major tectonic elements indicated with 394 dashed yellow lines [Zonenshain and Le Pichon, 1986]. Black box indicates area 395 shown in Figure 1b. b. Close-up of Mid Black Sea High showing sediment thickness 396 [Shillington et al., 2008] and OBS locations from 2005 experiment. Note that Mid397 Black Sea High separates the Western and Eastern basins of the Black Sea and 398 comprises two ridges: the Archangelsky Ridge and the Andrusov Ridge. Seismic 399 reflection profile 91-106 (Fig. 2) is shown with thick white line. It is coincident with 400 Profile 4 but shorter; it extends southwest to between OBS 3 and 4.

402 Figure 2. a. Seismic reflection profile 91-106 across the Mid-Black Sea High, which 403 is coincident with the Line 4 OBS profile (courtesy of BP and TPAO) (see Fig. 1 for 404 location). b. Seismic reflection profile with interfaces used in seismic inversion. The 405 blue, green and orange dotted lines show interpreted horizons used to invert for post406 and syn-rift sedimentary structure by Scott et al. [2009]. The red dotted line shows 407 the interpreted pre-rift sedimentary horizon used in the inversions presented here. 408

409 Figure 3. Receiver gather without picks (top panel). Data with observed picks and 410 picking errors (closed circles and bars) and predicted picks (solid, lighter colored 411 circles) (middle panel). Orange - PprP; Blue - Pg; Green - PmP; Red - Pn. Ray paths 
412 through final model from reflection/refraction tomography model. a. OBS 2, b.

413 OBS9, c. OBS13, d. OBS15.

416 Figure 4. a. Result of inversion for pre-rift sedimentary reflections (PprP) and first-

417 arriving refractions from crust and upper mantle (Pg and $\mathrm{Pn})$. Velocities contoured at

$4180.25 \mathrm{~km} / \mathrm{s}$. Velocity model is masked by density of ray coverage. b. Density of ray

419 coverage over the velocity model in a. c. Observed and predicted travel-time picks.

420 Uncertainty of observed picks indicated with bars. d. Travel-time residuals for picks.

422 Figure 5. a. Result of inversion for pre-rift sedimentary reflections (PprP), first-

423 arriving refractions from crust and upper mantle (Pg and $\mathrm{Pn}$ ), and reflections from the

424 base of the crust (PmP). Velocities contoured at $0.25 \mathrm{~km} / \mathrm{s}$. Velocity model masked by

425 density of ray coverage. b. Density of ray coverage over the velocity model in a. c.

426 Observed and predicted travel-time picks. Uncertainty of observed picks indicated

427 with bars. d. Travel-time residuals for picks.

429 Figure 6: Overlay of reflection profile 91-106 on final velocity model from

430 reflection/refraction tomography (Fig. 5), which was converted to two-way travel

431 time.

432

433 Figure 7: Comparison of crustal thinning factor (beta $=$ initial thickness/rifted

434 thickness) along Line 4 from subsidence analysis based on sediment thickness

435 [Shillington et al., 2008] and from this study assuming an initial crustal thickness of $436 \quad 35 \mathrm{~km}$. 


\section{References}

440

441

442

443

444

445

446

447

448

449

450

451

452

453

454

455

456

457

458

459

460

461

462

463

464

465

466

467

468

469

470

471

472

473

474

475

476

477

478

479

480

481

482

Aydemir, V., A Demirer (2013), Upper Cretaceous and Paleocene Shallow Water Carbonates along the Pontide Belt, Türkiye 19. Uluslararası Petrol ve Doğal Gaz Kongre ve Sergisi 15-17 May1s 2013, 284-290.

Banks, C. J., A. G. Robinson, and M. P. Williams (1997), Structure and regional tectonics of the Achara-Trialet fold belt and the adjacent Rioni and Kartli foreland basins, AAPG, Tulsa, OK.

Belousov, V. V., B. S. Volvovsky, I. V. Arkhipov, V. B. Buryanova, Y. D. Evsyukov, V. P. Goncharov, V. V. Gordienko, D. F. Ismagilov, G. K. Kislov, L. I. Kogan, V. N. Moskalenko, Y. P. Neprchnov, B. K. Ostisty, O. M. Rusakov, K. M. Shimkus, A. E. Shlenzinger, V. V. Sochelnikov, V. B. Sollogub, V. D. Solovyev, V. I. Starostenko, A. F. Starovoitov, A. A. Terekhov, I. S. Volvovsky, A. S. Zhigunov, and V. G. Zolotarev (1988), Structure and evolution of the earth's crust and upper mantle of the Black Sea, Bollettino Di Geofisica Teorica ed Applicata, 30 (117-118), 109-196.

Calvert, A. J. (2011), The Seismic Structure of Island Arc Crust, in Arc-Continent Collision, edited by D. Brown and P. D. Ryan, pp. 87-119, Springer-Verlag Berlin Heidelberg.

Christensen, N. I., and W. D. Mooney (1995), Seismic velocity structure and composition of the continental crust - a global view, Journal of Geophysical Research-Solid Earth, 100(B6), 9761-9788.

Espurt, N., J. C. Hippolyte, N. Kaymakci, and E. Sangu (2014), Lithospheric structural control on inversion of the southern margin of the Black Sea Basin, Central Pontides, Turkey, Lithosphere, 6(1), 26-34.

Gobarenko, V. S., A. V. Murovskaya, T. P. Yegorova, and E. E. Sheremet (2016), Collision processes at the northern margin of the Black Sea, Geotectonics, 50(4), 407-424.

Görür, N. (1988), Timing of opening of the Black Sea basin, Tectonophysics, 147(34), 247-262.

Hobro, J. W. D., S. C. Singh, and T. A. Minshull (2003), Three-dimensional tomographic inversion of combined reflection and refraction seismic traveltime data, Geophys. J. Int., 152, 79-93.

Holbrook, W. S., and P. B. Kelemen (1993), Large igneous province on the US Atlantic margin and implications for magmatism during continental breakup, Nature, 364, 433-436.

Kazmin, V. G., A. A. Schreider, and A. A. Bulychev (2000), Early stages of evolution of the Black Sea, in Tectonics and Magmatism in Turkey and the Surrounding Area, edited by E. Bozkurt, et al., pp. 235-249, Geological Society, London.

Kodaira, S., T. Sato, N. Takahashi, A. Ito, Y. Tamura, Y. Tatsumi, and Y. Kaneda (2007), Seismological evidence for variable growth of crust along the Izu intraoceanic arc, J. Geophys. Res., 112(B5), B05104.

Letouzey, J., B. Biju-Duval, A. Dorkel, R. Gonnard, K. Kristchev, L. Montadert, and O. Sungurlu (1977), The Black Sea: A Marginal Basin, Geophysical and Geological Data, in International Symposium of the Mediterranean Basins Split 
(Yugoslavia) 25-29 October 1976, edited by B. Biju-Duval and L. Montadert, pp. 363-376, Editions Technip, Paris.

Marin-Moreno, H., T. A. Minshull, and R. A. Edwards (2013a), Inverse modelling and seismic data constraints on overpressure generation by disequilibrium compaction and aquathermal pressuring: application to the Eastern Black Sea Basin, Geophysical Journal International, 194(2), 814-833.

Marin-Moreno, H., T. A. Minshull, and R. A. Edwards (2013b), A disequilibrium compaction model constrained by seismic data and application to overpressure generation in The Eastern Black Sea Basin, Basin Research, 25(3), 331-347.

Nikishin, A. M., M. V. Korotaev, A. V. Ershov, and M.-F. Brunet (2003), The Black Sea basin: tectonic history and Neogene-Quaternary rapid subsidence modelling, Sedimentary Geology, 156, 149-168.

Nikishin, A. M., A. Okay, O. Tuysuz, A. Demirer, M. Wannier, N. Amelin, and E. Petrov (2015a), The Black Sea basins structure and history: New model based on new deep penetration regional seismic data. Part 2: Tectonic history and paleogeography, Marine and Petroleum Geology, 59, 656-670.

Nikishin, A. M., A. I. Okay, O. Tuysuz, A. Demirer, N. Amelin, and E. Petrov (2015b), The Black Sea basins structure and history: New model based on new deep penetration regional seismic data. Part 1: Basins structure and fill, Marine and Petroleum Geology, 59, 638-655.

Okay et al, THIS VOLUME

Okay, A. I., A. M. C. Sengor, and N. Görür (1994), Kinematic history of the opening of the Black Sea and its effect on the surrounding regions, Geology, 22, 267270.

Okay, A. I., G. Sunal, S. Sherlock, D. Altiner, O. Tüysüz, A. R. C. Kylander-Clark, and M. Aygül (2013), Early Cretaceous sedimentation and orogeny on the active margin of Eurasia: Southern Central Pontides, Turkey, Tectonics, 32, 1247 1271.

Ozacar, A. A., G. Zandt, H. Gilbert, and S. L. Beck (2010), Seismic images of crustal variations beneath the East Anatolian Plateau (Turkey) from teleseismic receiver functions, in Sedimentary Basin Tectonics from the Black Sea and Caucasus to the Arabian Platform, edited by M. Sosson, et al., pp. 485-496, Geological Soc Publishing House, Bath.

Rangin, C., A. G. Bader, G. Pascal, B. Ecevitoglu, and N. Görür (2002), Deep structure of the Mid Black Sea High (offshore Turkey) imaged by multi-channel seismic survey (BLACKSIS cruise), Marine Geology, 182, 265-278.

Robertson, A. H. F., T. Ustaömer, E. A. Pickett, A. S. Collins, T. Andrew, and J. E. Dixon (2004), Testing models of Late-Palaeozoic-Early Mesozoic orogeny in Western Turkey: support for an evolving open-Tethys model, J. Geol. Soc. London, 161, 501-511.

Robinson, A. G., C. J. Banks, M. M. Rutherford, and J. P. P. Hirst (1995), Stratigraphic and structural development of the Eastern Pontides, Turkey, J. Geol. Soc. London, 152, 861-872.

Robinson, A. G., J. H. Rudat, C. J. Banks, and R. L. F. Wiles (1996), Petroleum Geology of the Black Sea, Marine Petrol. Geol., 13(2), 195-223.

Rudat, J. H., and D. S. Macgregor (1993), Unconventional exploration techniques in a high cost deep water basin: a case study from the Black Sea, Soc. of Explor. Geophys. Abstr. Progr. 
Saintot, A., and J. Angelier (2002), Tectonic paleostress fields and structural evolution of the NW-Caucaus fold-and-thrust belt from Late Cretaceous to Quaternary, Tectonophysics, 357, 1-31.

Scott, C. L., D. J. Shillington, T. A. Minshull, R. A. Edwards, P. J. Brown, and N. J. White (2009), Wide-angle seismic data reveal extensive overpressures in Eastern Black Sea, Geophys. J. Int., 178, 1145-1163, doi: 1110.1111/j.13651246X.2009.04215.x.

Shillington, D. J., H. J. A. Van Avendonk, W. S. Holbrook, P. B. Kelemen, and M. J. Hornbach (2004), Composition and structure of the central Aleutian island arc from arc-parallel wide-angle seismic data, Geochem. Geophys. Geosys., 5(Q10006), doi:10.1029/2004GC000715.

Shillington, D. J., N. White, T. A. Minshull, G. R. H. Edwards, S. Jones, R. A. Edwards, and C. L. Scott (2008), Cenozoic evolution of the eastern Black Sea: a test of depth-dependent stretching models, Earth Planet. Sci. Lett., 265(3-4), 360-378.

Shillington, D. J., C. L. Scott, T. A. Minshull, R. A. Edwards, P. J. Brown, and N. White (2009), Abrupt transition from magma-starved to magma-rich rifting in the eastern Black Sea, Geology, 37(1), 7-10, doi:10.1130/G25302A.25301.

Starostenko, V., V. Buryanov, I. Makarenko, O. Rusakov, R. Stephenson, A. Nikishin, G. Georgiev, M. Gerasimov, R. Dimitriu, O. Legostaeva, V. Pchelarov, and C. Sava (2004), Topography of the crust-mantle boundary beneath the Black Sea Basin, Tectonophysics, 381, 211-233.

Tari, G., Schleder, Zs., Fallah, M., Turi, V., Kosi, W. and Krezsek, Cs., (2015). Regional rift structure of the Western Black Sea Basin: map-view kinematics. Transactions GCSSEPM Foundation Perkins-Rosen 34th Annual Research Conference "Petroleum Systems in Rift Basins", Houston, Texas, 372-396.

Töksöz, M. N., C. H. Cheng, and A. Timur (1976), Velocities of seismic waves in porous rocks, Geophysics, 41, 621-645.

Vincent, S. J., M. B. Allen, A. D. Ismail-Zadeh, R. Flecker, K. A. Foland, and M. D. Simmons (2005), Insights from the Talysh of Azerbaijan into the Paleogene evolution of the South Caspian region, GSA Bulletin, 117(11/12), 1513-1533.

White, R. S., L. K. Smith, A. W. Roberts, P. A. F. Christie, N. J. Kusznir, and iSIMM Team (2008), Lower-crustal intrusion on the North Atlantic continental margin, Nature, 452, 460-465.

Yegorova, T., and V. Gobarenko (2010), Structure of the Earth's crust and upper mantle of the West- and East-Black Sea Basins revealed from geophysical data and its tectonic implications, in Sedimentary Basin Tectonics from the Black Sea and Caucasus to the Arabian Platform, edited by M. Sosson, et al., pp. 2342, Geological Soc Publishing House, Bath.

Yegorova, T., V. Gobarenko, and T. Yanovskaya (2013), Lithosphere structure of the Black Sea from 3-D gravity analysis and seismic tomography, Geophysical Journal International, 193(1), 287-303.

Yilmaz, Y., O. Tüysüz, E. Yigitbas, S. Genç, Can, and A. M. C. Sengör (1997), Geology and Tectonic Evolution of the Pontides, in Regional and petroleum geology of the Black Sea and surrounding region: AAPG Memoir 68, edited by A. G. Robinson, pp. 183-226, AAPG, Tulsa.

Zonenshain, L. P., and X. Le Pichon (1986), Deep Basins of the Black Sea and Caspian Sea as Remnants of Mesozoic Back-Arc Basins, Tectonophysics, 123, $181-211$ 
Table 1: Relocated OBS positions

\begin{tabular}{|c|c|c|}
\hline OBS & Latitude $\left({ }^{\circ} \mathbf{N}\right)$ & Longitude $\left({ }^{\circ} \mathrm{E}\right)$ \\
\hline 1 & 42.511005 & 35.212699 \\
\hline 2 & 42.549179 & 35.322692 \\
\hline 3 & 42.589855 & 35.432331 \\
\hline 4 & 42.625923 & 35.543609 \\
\hline 5 & 42.663829 & 35.654865 \\
\hline 6 & 42.701 & 35.766201 \\
\hline 7 & 42.738536 & 35.876911 \\
\hline 8 & 42.777019 & 35.987457 \\
\hline 9 & 42.813636 & 36.09951 \\
\hline 10 & 42.851139 & 36.21101 \\
\hline 11 & 42.887451 & 36.323356 \\
\hline 12 & 42.925537 & 36.434604 \\
\hline 13 & 42.960388 & 36.540924 \\
\hline 14 & 42.995098 & 36.645301 \\
\hline 15 & 43.035087 & 36.765087 \\
\hline 16 & 43.073787 & 36.882984 \\
\hline 17 & 43.10337 & 36.974617 \\
\hline
\end{tabular}


Table 2

\begin{tabular}{lrlr} 
Phase & \multicolumn{1}{l}{$\begin{array}{l}\text { Number } \\
\text { Picks }\end{array}$} & $\begin{array}{l}\text { Chi } \\
\text { Squared }\end{array}$ & RMS Misfit (s) \\
PprP & 866 & 3.442881645 & 0.129567735 \\
Pg & 5334 & 2.038537344 & 0.106868266 \\
PmP & 1502 & 2.182268919 & 0.182210481 \\
Pn & 249 & 2.604642144 & 0.200007259
\end{tabular}



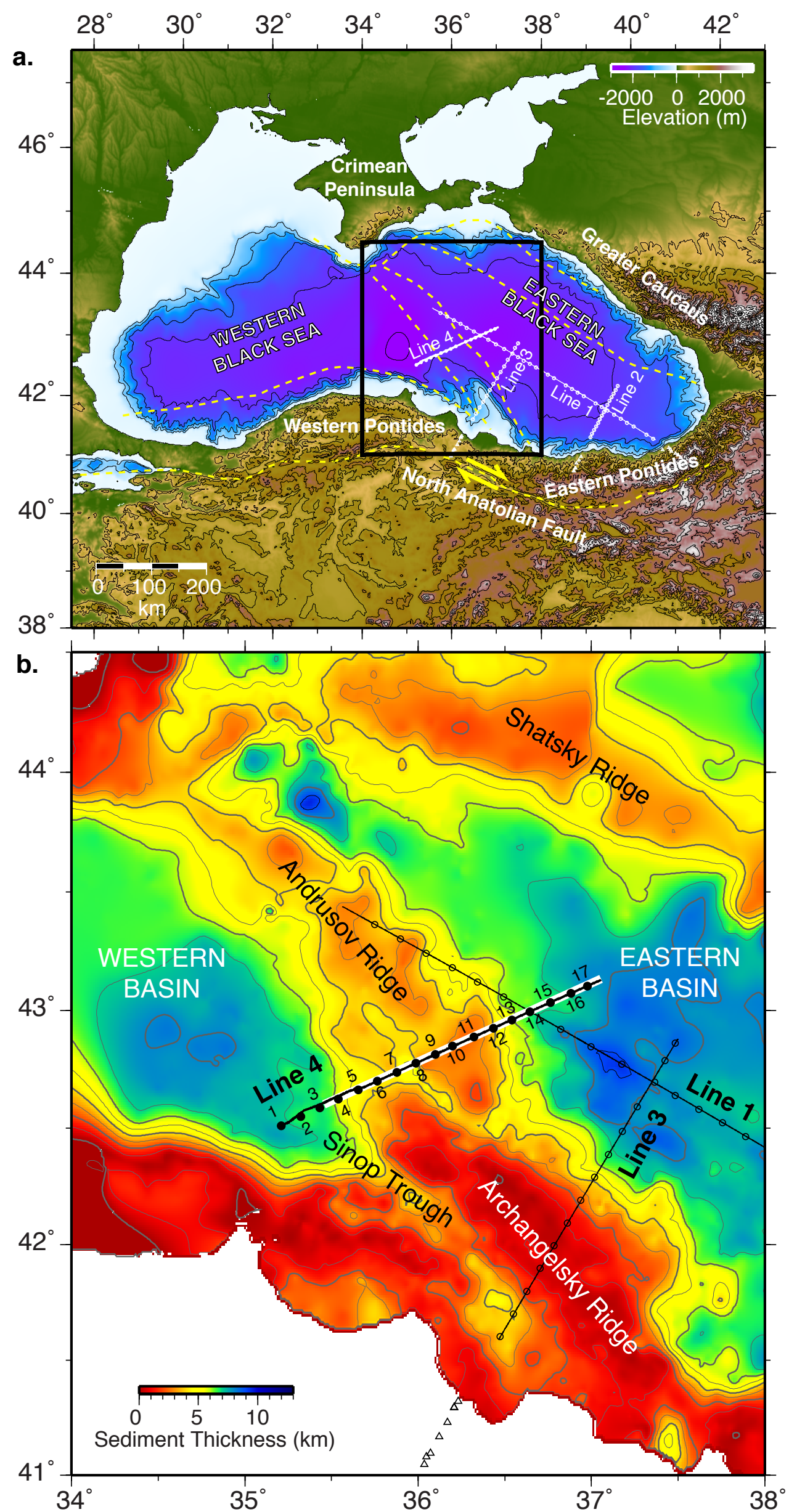
Figure 2

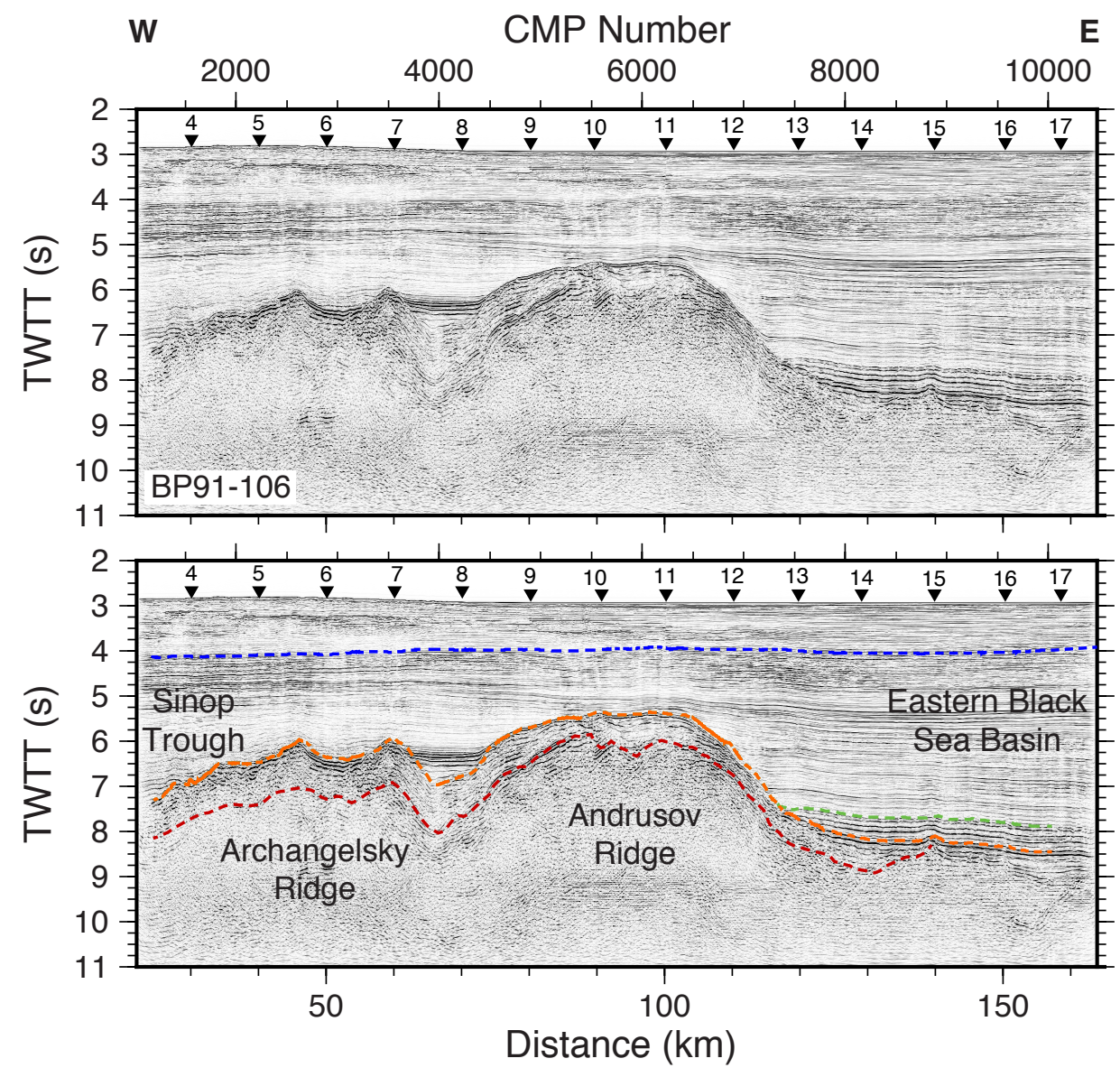


Figure 3

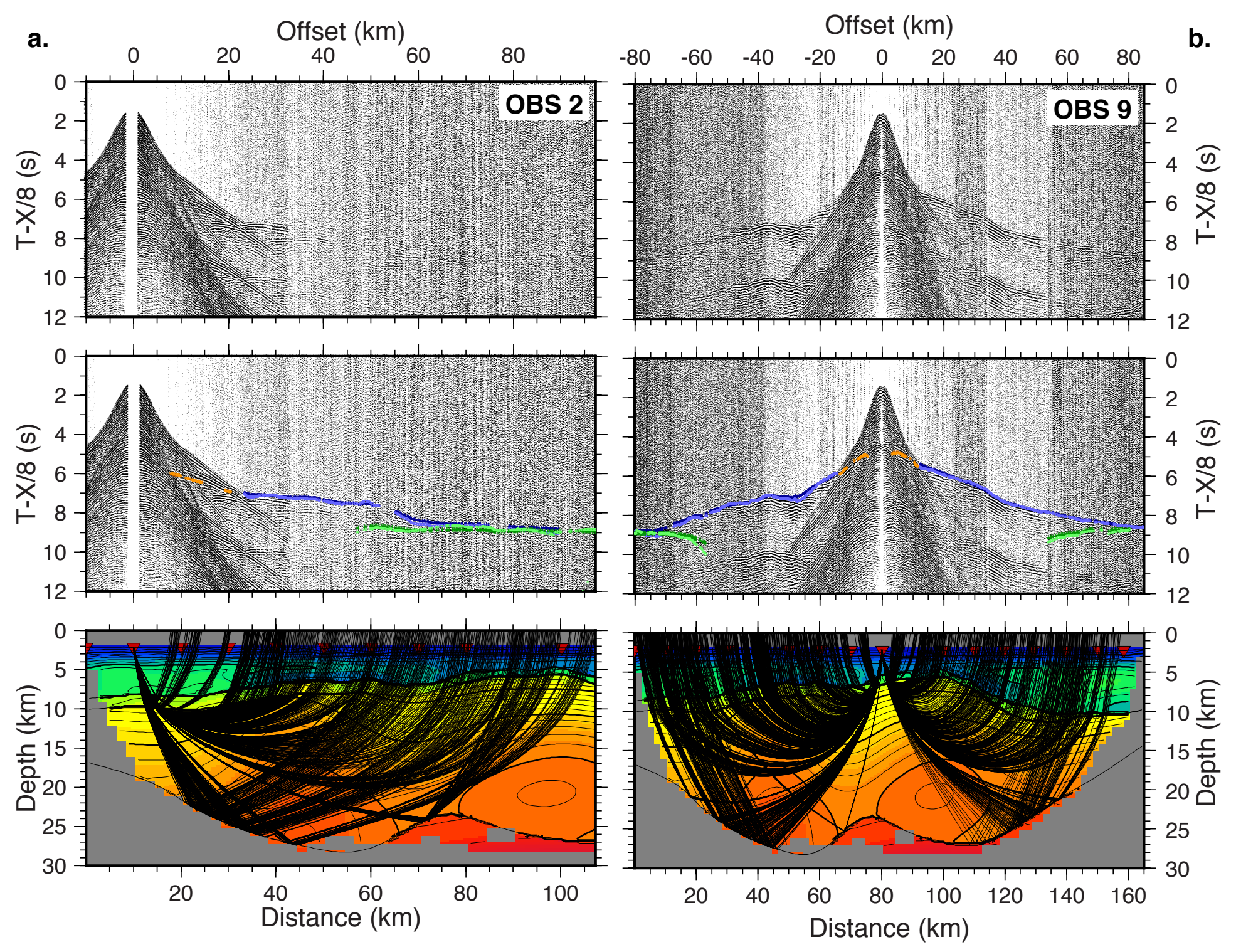


Figure 3
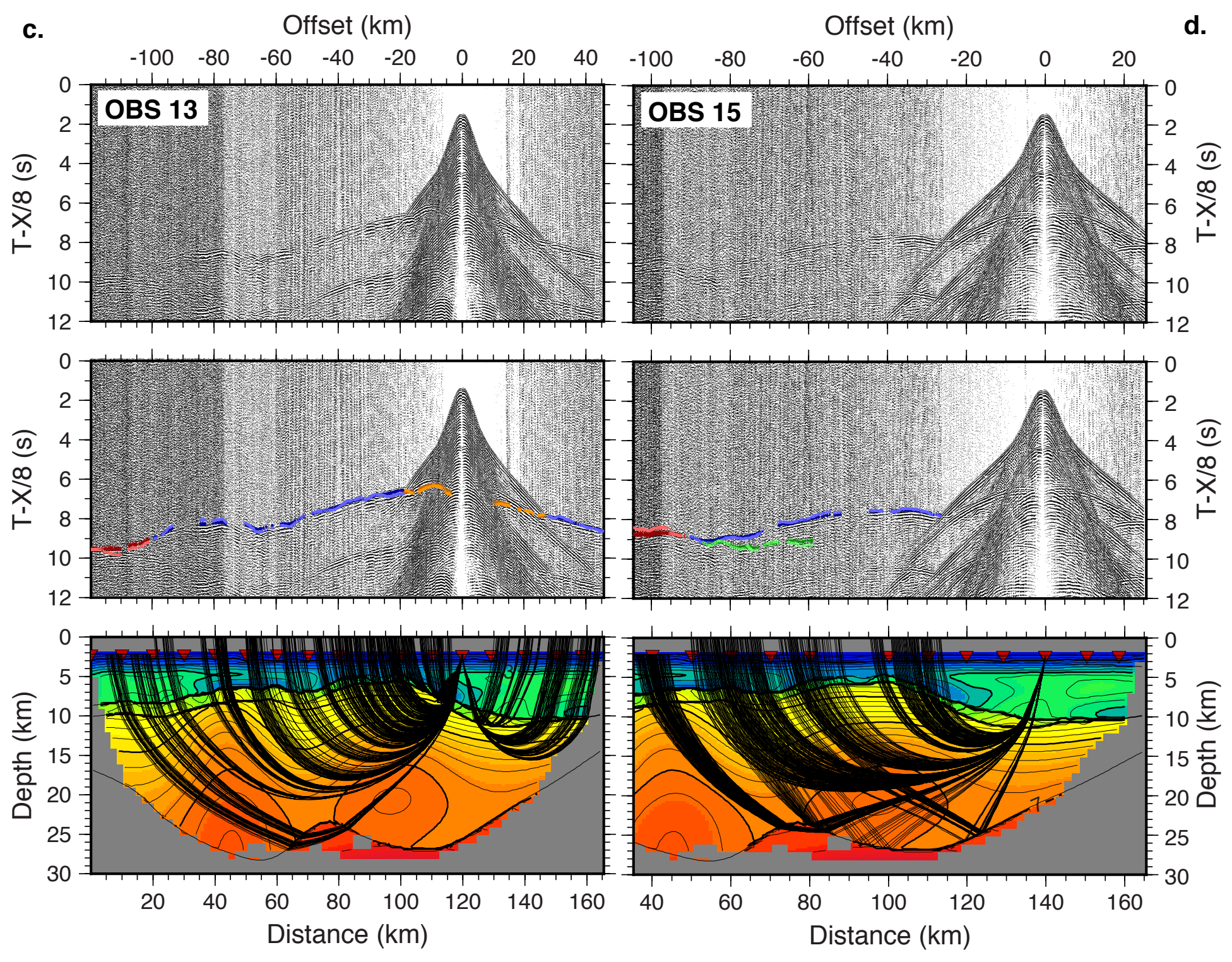


\section{Figure 4}
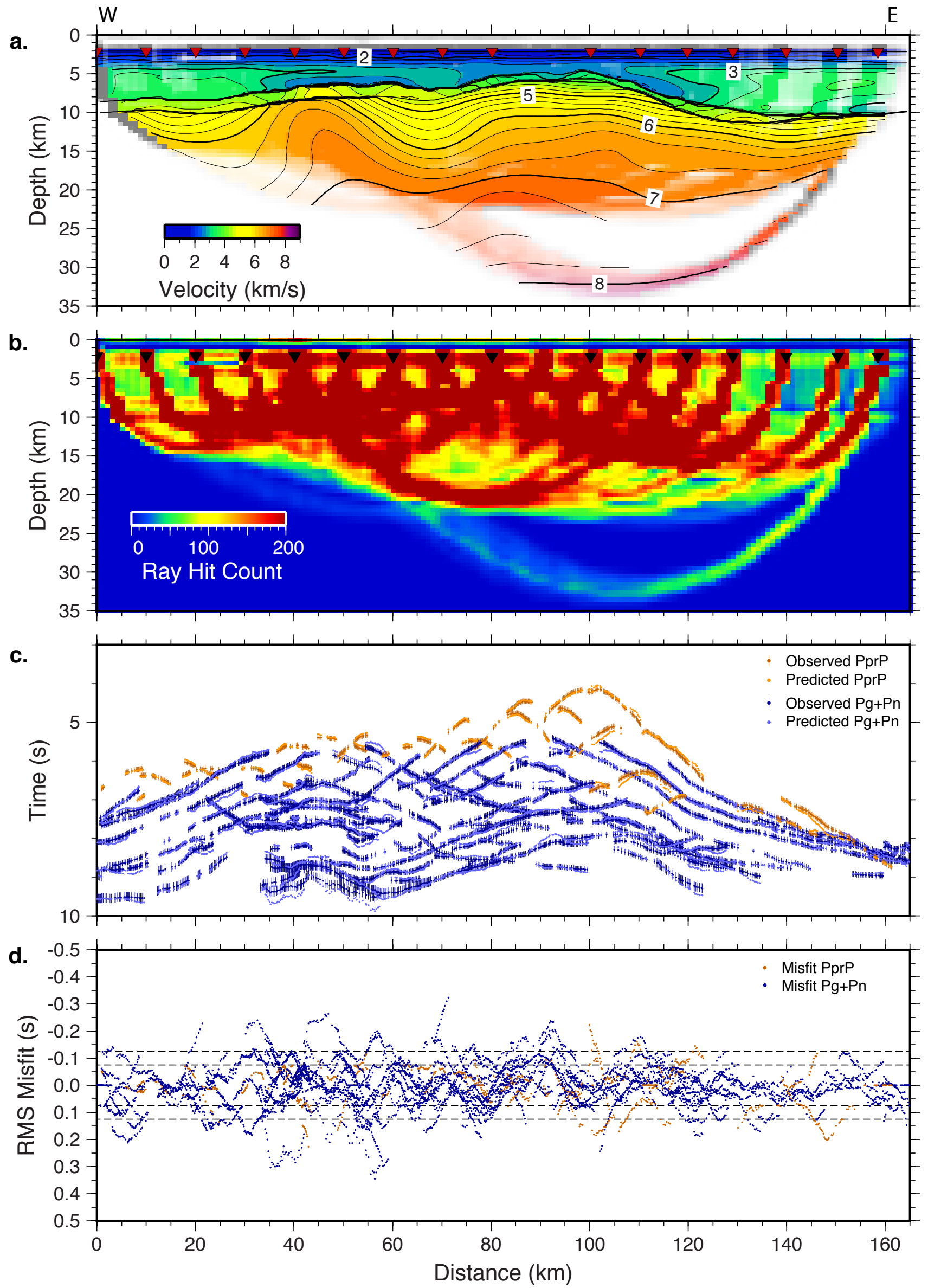
Figure 5
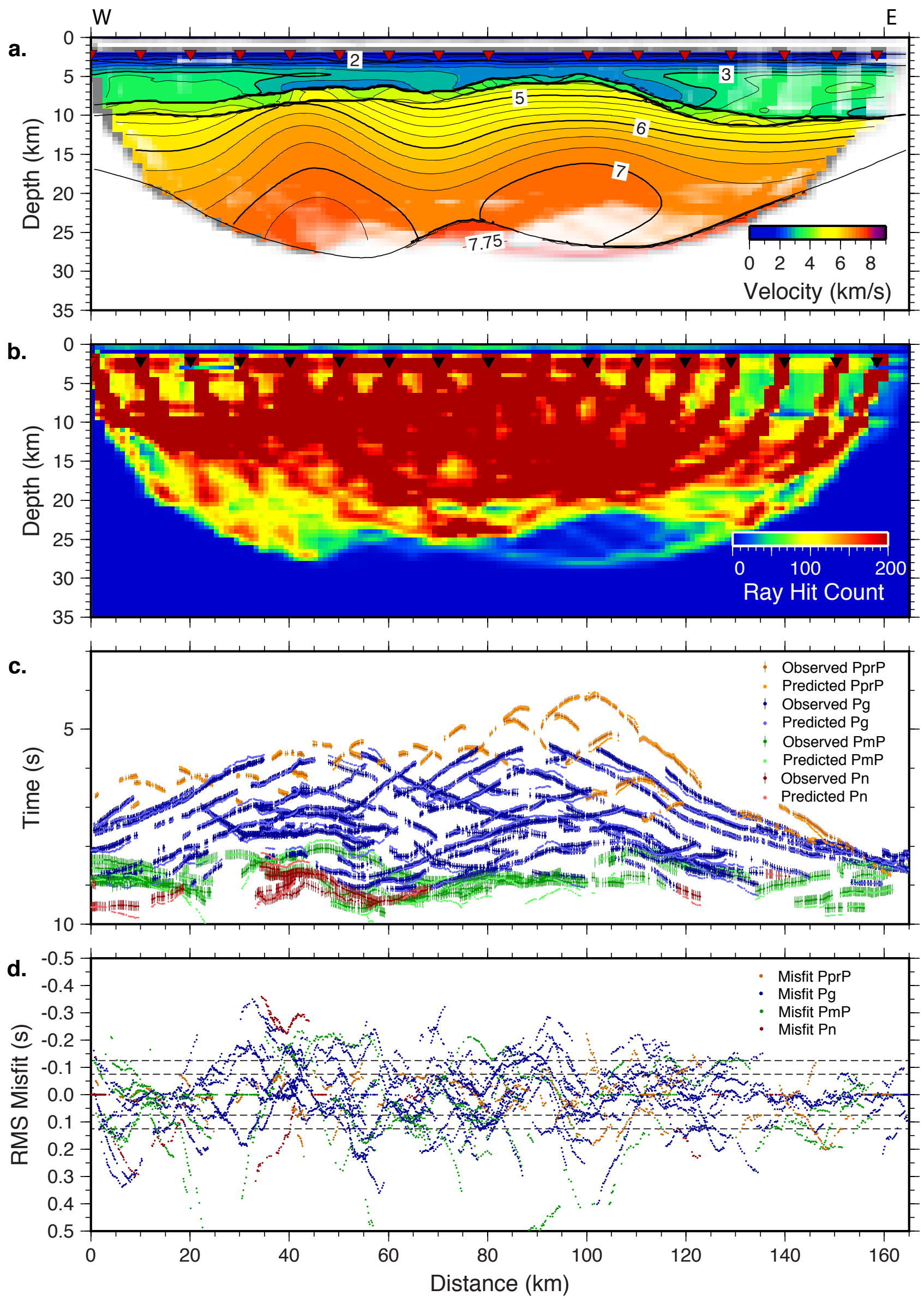
Figure 6
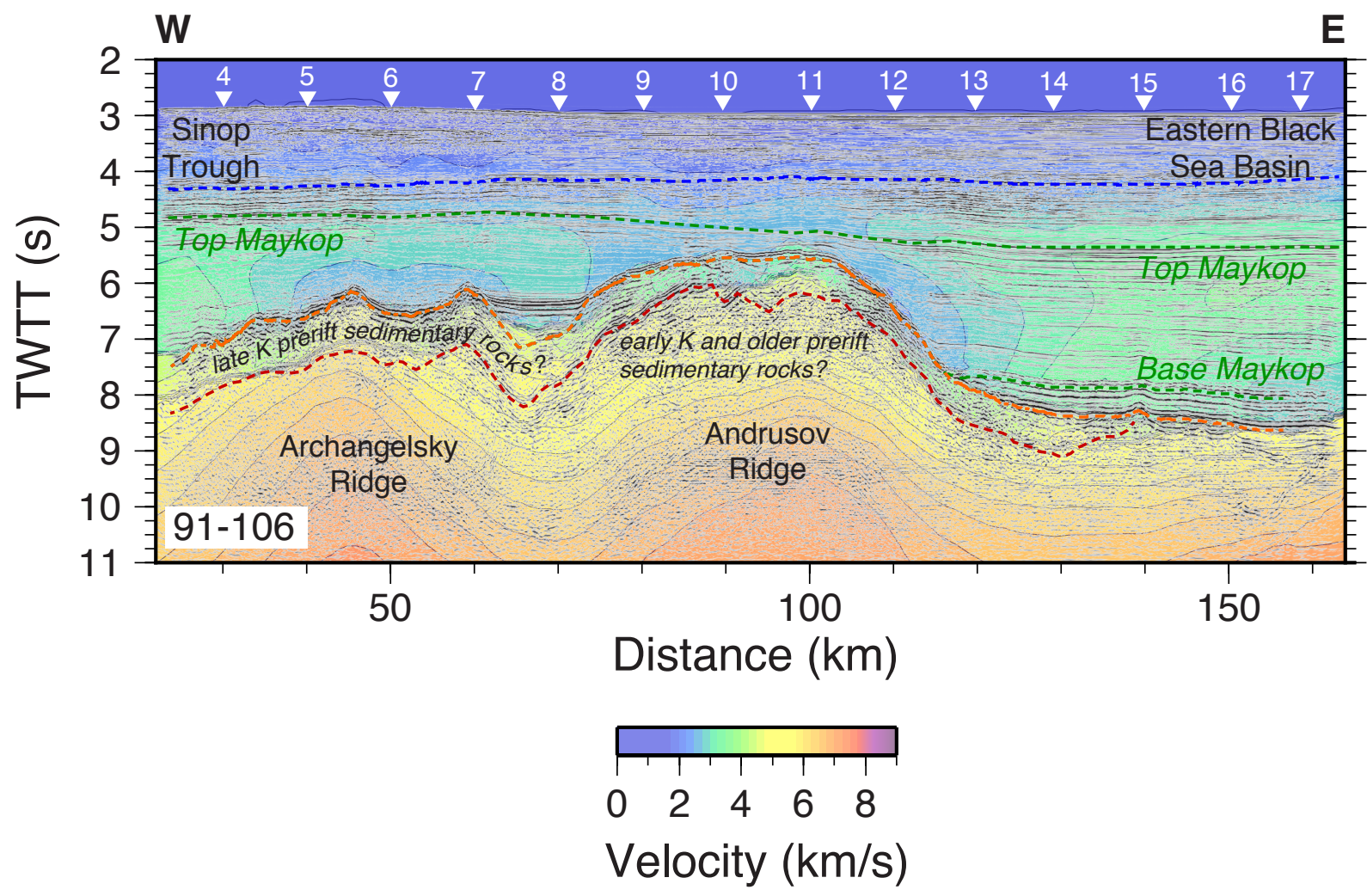
Figure 7

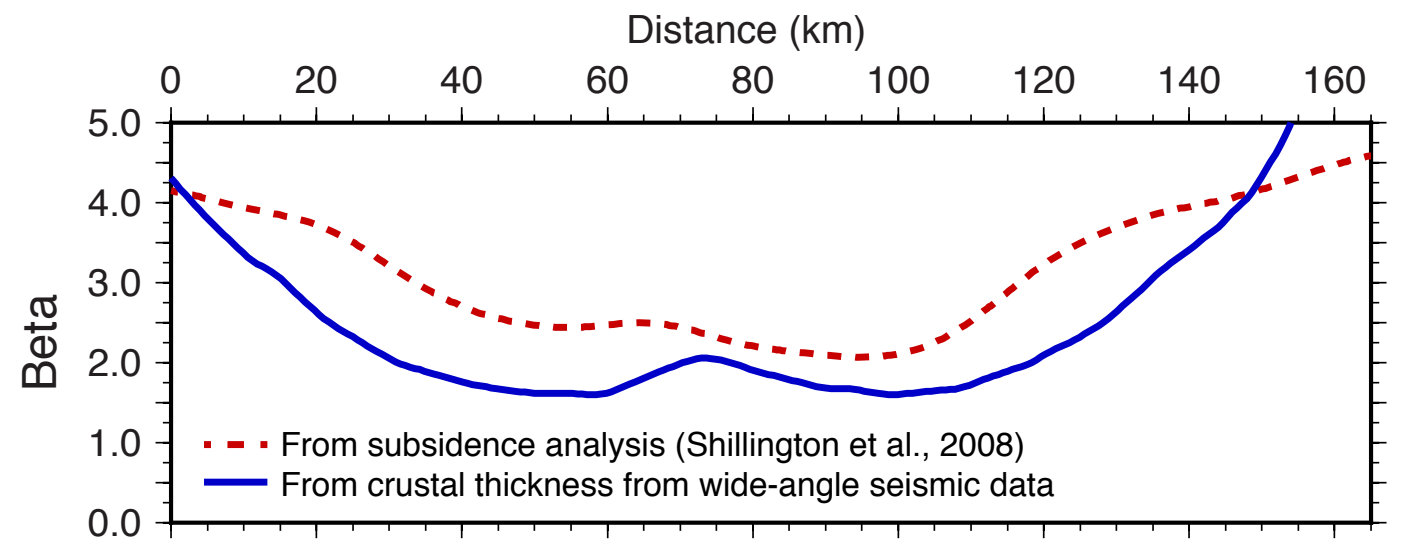

